\title{
Navike učenika u samovrednovanju postignuća učenja
}

\author{
Irena Labak ${ }^{1}$, Ines Kligl ${ }^{1}$ \\ ${ }_{1}$ Odjel za biologiju, Sveučilište J. J. Strossmayera u Osijeku, Ulica Cara Hadrijana 8/A, 31000 Osijek, Hrvatska \\ ilabak@biologija.unios.hr
}

\begin{abstract}
SAŽETAK
Istraživanje je provedeno s ciljem utvrđivanja navika samovrednovanja postignuća kod učenika srednje škole i uočavanja razlika učenika u navikama samovrednovanja s obzirom na spol i školski uspjeh. Istraživanje se provelo školske godine 2018./2019. na uzorku od 61 učenika trećih razreda jedne osječke gimnazije. Provedena je pisana provjera znanja i anketa. U pisanoj provjeri znanja usporedio se očekivan i ostvaren broj bodova radi objektivne prosudbe učeničke sposobnosti samoprocjene postignuća. Subjektivan doživljaj sposobnosti točne samoprocjene postignuća kao i ostale navike samovrednovanja utvrđene su anketom. Provedenim istraživanjem je utvrđen nesklad između ostvarenog i očekivanog uspjeha, kao i nesklad između percipirane i stvarne sposobnosti točne samoprocjene vlastitog uspjeha. Učenici precjenjuju svoj uspjeh i vlastite mogućosti samoprocjene znanja. Također je utvrđeno da postoji svijest o važnosti samovredovanja, ali im nedostaju navike i iskustvo u toj vještini.
\end{abstract}

Ključne riječi: samovrednovanje; samorefleksija; povratne informacije; pristupi vrednovanja

\section{UVOD}

Cilj obrazovnog procesa je ovladavanje vještinama upravljanja učenjem te usmjeravanje učenika na razvoj kompetencija. U ostvarivanju navedenog cilja svakodnevno djeluje učitelj/nastavnik prilikom neposrednog planiranja. Pri tome polazeći od zadanog standarda (propisani ishodi u predmetnom kurikulumu i propisana očekivanja u kurikulumu međupredmetnih tema) planira što se uči, kako se uči i kako se vrednuje.

Vrednovanje je neodvojivo od učenja/poučavanja. Općenito se pojam vrednovanja, kada se govori o obrazovanju, odnosi na usmjeravanje razvoja i napredovanja učenika prema odgojno-obrazovnim ciljevima. Prema Matijević (2004) vrednovanjem (prikupljanjem, analiziranjem i interpretiranjem informacija) procjenjujemo stupanj ostvarivanja ciljeva nastave. Također vrednovanjem određujemo vrijednosti nekoj aktivnosti ili rezultatu aktivnosti učenika u nastavnom procesu. Dakle, vrednuje se kako proces učenja tako i kao produkt učenja (postignuće). U nastavnoj praksi vrednovanje podrazumijeva praćenje, procjenjivanje i ocjenjivanje. Praćenjem učitelji/nastavnici uočavaju kvalitete i slabosti svakog pojedinog učenika i na osnovu toga planiraju i usmjeravaju učenikov razvoj, ali i interveniraju na uočene poteškoće (Cindrić i sur, 2010). Svrha provjeravanja slična je praćenju s razlikom da se praćenje provodi kontinuirano, dok se provjeravanje provodi učestalo (Hunjek, 2015). Praćenje i provjeravanje dio su formativnog vrednovanja odnosno pristupa vrednovanja za učenje. Sustavnom i kontinuiranom uporabom pristupa vrednovanja za učenje osigurava se učeniku i učitelju/nastavniku povratna informacija o uspješnosti učenja/poučavanja. Na temelju prikupljenih informacija planira se daljnje učenje te se mijenja praksa poučavanja kako bi učenici unaprijedili učenje (Earl i Katz, 2006). Povratna informacija se pruža tijekom procesa učenja jer ga unaprjeđuje jedino ako je njegov sastavni dio (Penca Palčić, 2008). Kako bi bila korisna daje se učenicima dok su još uvijek okupirani temom, zadatkom ili aktivnošću. U suprotnom će ju učenici smatrati beskorisnom (Brookhart, 2008). Povratne informacije treba shvatiti kao zajedničku odgovornost nastavnika i učenika (Cowie, 2005). Osim prakse pružanja povratnih informacija od strane učitelja/nastavnika, povratnu informaciju mogu si i trebaju dati i sami učenici putem samovrednovanja (Andrade i Valtcheva, 2009).

Labak, I., Kligl, I. (2019). Navike učenika u samovrednovanju postignuća učenja. Educ. biol., 5:1-12. URL DOI: https://doi.org/10.32633/eb.5.1 
Samovrednovanje se koristi u formativne svrhe kako bi se unaprijedilo učenje i potaknulo praćenje i upravljanje vlastitim učenjem (Wong, 2017). Samovrednovanje, kao temeljni koncept samoreguliranog učenja poboljšava motivaciju, autonomiju u učenju (Brown i Harris, 2013) i razvoj metakognitivnih vještina (Zimmerman i Moylan, 2009). Ono je vještina koja se razvija i uči, a prema Matijević (2004) učenike treba započeti osposobljavati za samovrednovanje već u prvim danima osnovne škole i dalje nastaviti tijekom čitavog školovanja. Kada stupanj samostalnosti i prakse samovrednovanja prevlada stupanj pomoći i podrške nastavnika, učenici se u reguliranju učenja više oslanjaju na vlastito oblikovane povratne informacije nego na nastavnikove.

Samovrednovanje, uz motivaciju, pozitivno djeluje na školski uspjeh (Bursać i sur, 2016; Duckworth i Seligman, 2005; Suchodoletz i sur, 2009). Utjecaj samovrednovanja na učenička postignuća je u tome što samovrednovanje omogućava učenicima kontrolu vlastitog učenja i usvajanje kriterija vrednovanja (McMillan i Hearn, 2008). Također pozitivno utječe na afektivnu domenu učenja (Cavilla, 2017). Razina postignuća i praksa samovrednovanja razlikuju se između učenika i učenica u korist učenica (Duckworth i Seligman, 2006; Kuhl i Hannover, 2012). Djevojčice koriste značajno više strategija za samoregulirano učenje nego dječaci (de Bilde, i sur, 2011; Kadhiravan, 2012).

S obzirom da je samovrednovanje procesa i produkta učenja vještina koja se razvija te koja, ovisno o spremnosti učenika za samovrednovanje, zahtijeva određenu razinu pomoći i podrške od strane učitelja/nastavnika potrebno je poznavati navike i stupanj samostalnosti učenika u provođenju ove vještine. Stoga je cilj provedenog istraživanja utvrditi navike samovrednovanja postignuća kod učenika srednje škole i uočiti razlikuju li se učenici u navikama samovrednovanja s obzirom na spol i školski uspjeh.

\section{METODE}

Istraživanje je provedeno školske godine 2018./2019. U njemu su bila obuhvaćena tri razreda jedne osječke gimnazije s ukupno 61 učenikom.

Dvije etape su bile prisutne $u$ istraživanju. $U$ prvoj etapi provedena je pisana provjera znanja koja je sastavljena za potrebe ovog istraživanja na temelju udžbenika iz biologije za prvi razred gimnazije kojeg je odobrilo Ministarstvo znanosti, obrazovanja i sporta (Bogut i sur., 2012). Provjera znanja sastojala se od 9 pitanja, od kojih je 1., 2., 3. i 9. pitanje bilo raščlanjeno pa je u skladu s tim pisana provjera sadržavala ukupno 21 pitanje. Od toga su prvu razinu postignuća (R1 - reproduktivno znanje) ispitivala 3 pitanja, dok je preostalih 18 pitanja ispitivalo drugu razinu postignuća (R2 - razumijevanje i primjena znanja, prema Crooksovoj taksonomiji, 1988). Pitanja su bila vezana uz nastavne teme "Mitoza“, „Mejoza“ $\mathrm{i}$ „Gametogeneza“. Uz svako pitanje bio je naznačen broj bodova koji učenik može ostvariti uz uvjet potpuno točnog odgovora. Učenici su nakon svakog riješenog pitanja procjenjivali točnost svog odgovora i upisivali očekivane bodove u za to predviđeno mjesto. Na taj je način analiziran i uspoređen ostvaren i očekivan broj bodova kako bi se objektivno prosudila sposobnost učenika za točnom samoprocjenom vlastitog uspjeha na pisanoj provjeri znanja.

U drugoj etapi s učenicima je provedena anketa također sastavljena za potrebe ovog istraživanja. Anketa se sastojala od dva dijela. Prvi dio ankete ispitao je učenikov spol i zaključnu ocjenu iz biologije na kraju 2. razreda. Drugi dio ankete sastojao se od 25 tvrdnji vezanih uz ispitivanje navika samovrednovanja. Svaku tvrdnju učenici su trebali procijeniti skalom od 1 do 5 (1 - nikada, 2 - rijetko, 3 - povremeno, 4 - prilično često, 5 - uvijek) prema kojoj su procijenili mjeru prisutnosti pojedine tvrdnje u njihovom učenju odnosno poučavanju biologije (odabir skale prema Burušić, 1999). Za anketu 
provedenu s učenicima izračunat je Cronbachov alfa koeficijent koji iznosi 0,72 što se tumači kao prihvatljivo pouzdana anketa ( $72 \%$ varijance objašnjeno je pravim rezultatima, dok se $28 \%$ varijance može pripisati pogrešci). Anketom se utvrdio subjektivan doživljaj sposobnosti točne samoprocjene postignuća kao i ostale navike samovrednovanja.

Povezanost navika samovrednovanja utvrđenih anketom s uspjehom učenika utvrđenog na pisanoj provjeri znanja utvrdio se Pearsonovim koeficijentom korelacije na razini $\alpha=0,05$. Statistički testovi provedeni su u statističkom programskom paketu Statistika 12 (Quest Software Inc., Aliso Viejo, CA, SAD).

\section{REZULTATI I RASPRAVA}

Uspješnost učenika u samoprocjeni vlastitog uspjeha na pisanoj provjeri znanja analizirana je usporedbom prosječnog broja ostvarenih i očekivanih bodova. Učenici su na pisanoj provjeri znanja prosječno ostvarili 2,54 boda, dok su prosječno očekivali 11,56 bodova (slika 1). Učenici su, dakle, prosječno očekivali 9,02 boda više nego što su uistinu ostvarili.

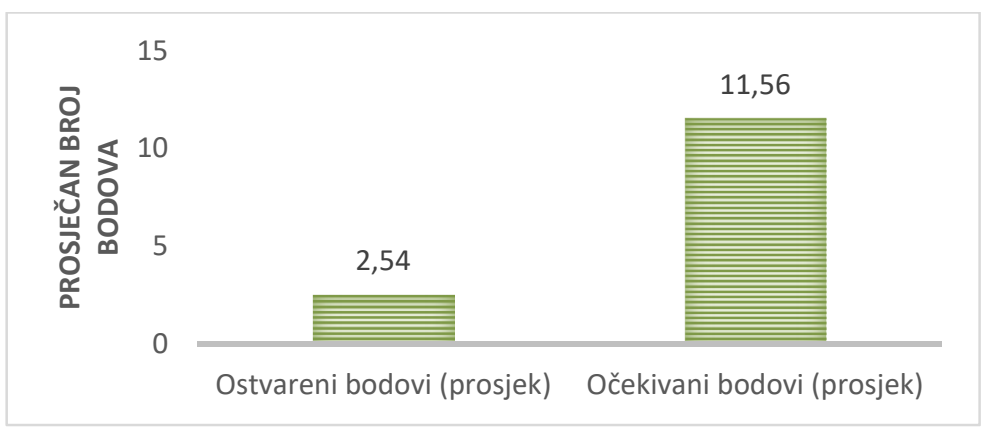

Slika 1 Usporedba prosječnog broja ostvarenih i očekivanih bodova učenika na pisanoj provjeri znanja

S obzirom na prikazani rezultat, analizirana je anketa o navikama samovrednovanja. Grafički su prikazani odgovori samo pojedinih tvrdnji ankete kako bi se objasnio rezultat prikazan na slici 1. Ostale tvrdnje prikazane su u prilogu 1.

Većina učenica smatra kako prilično često može točno procijeniti svoj uspjeh na pisanoj provjeri znanja, dok većina učenika smatra kako to može učiniti tek povremeno. Važno je uočiti da manji broj učenika oba spola smatra kako nikada i rijetko može točno procijeniti svoj uspjeh na pisanoj provjeri znanja (Slika 2A).

Učenik sa zaključnom ocjenom dovoljan (2) smatra kako prilično često može točno procijeniti svoj uspjeh na pisanoj provjeri znanja, učenici sa zaključnom ocjenom dobar (3) većinom smatraju kako to mogu učiniti povremeno, dok učenici sa zaključnom ocjenom vrlo dobar (4) većinom smatraju kako prilično često i uvijek mogu točno procijeniti svoj uspjeh na pisanoj provjeri znanja (Slika 2B).

Većina učenica sa zaključnom ocjenom dobar (3) smatra kako rijetko može točno procijeniti svoj uspjeh na pisanoj provjeri znanja, dok većina učenica sa zaključnom ocjenom vrlo dobar (4) smatra da to može učiniti povremeno i prilično često. S druge strane, većina učenica sa zaključnom ocjenom odličan (5) smatra da prilično često može točno procijeniti svoj uspjeh na pisanoj provjeri znanja (Slika 2C).

Također je i odgovor na 20. pitanje u kojem većina učenika odgovara da nikad ili rijetko zajedno s nastavnikom osmišljava kriterije ocjenjivanja ( $p r i l o g 1)$ povezan s uspjehom $(r=0.290 ; p=0.023$ ). 

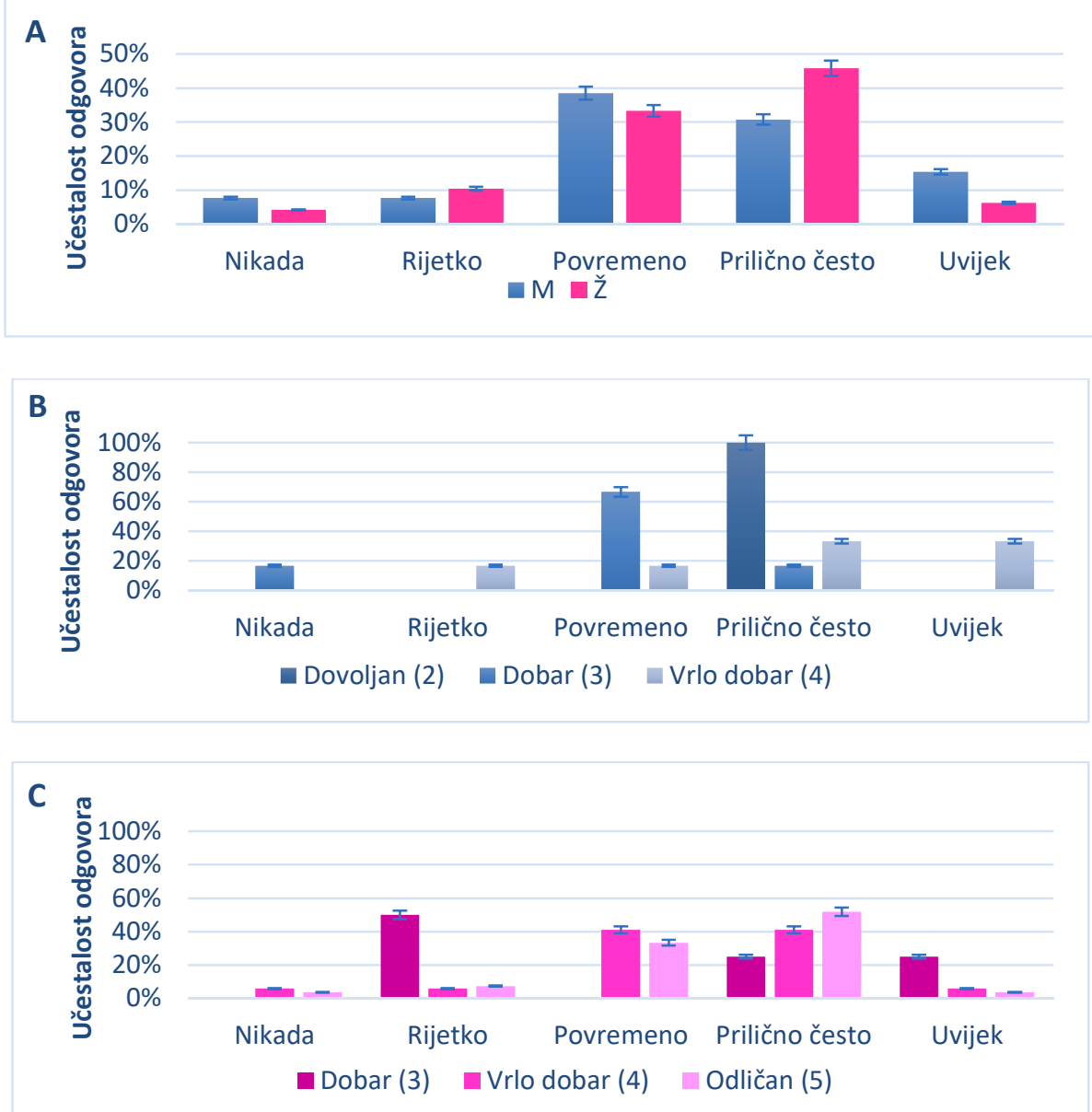

Slika 2 Usporedba odgovora učenika i učenica na tvrdnju „Mogu točno procijeniti svoj uspjeh na pisanoj provjeri znanja (ocjenu, točne i netočne odgovore) prije nego što dobijem rezultat od nastavnika." A usporedba odgovora s obzirom na spol; B usporedba odgovora s obzirom na zaključnu ocjenu iz biologije kod učenica

Većina učenika oba spola rijetko i povremeno preispituje svoje razumijevanje za vrijeme nastavnog sata. Manji broj učenica nikada ne preispituje svoje razumijevanje za vrijeme nastavnog sata, dok za razliku od njih ni jedan učenik nije odabrao taj odgovor. Također, manji broj učenica prilično često $\mathrm{i}$ uvijek preispituje svoje razumijevanje za vrijeme nastavnog sata, dok manji broj učenika prilično često preispituje svoje razumijevanje za vrijeme nastavnog sata, ali za razliku od učenica ni jedan učenik svoje razumijevanje za vrijeme nastavnog sata ne preispituje uvijek (Slika 3A). Utvrđena je povezanost $(r=$ 0,$289 ; p=0,024$ ) ovog pitanja i uspjeha pisane provjere znanja (srednja vrijednost ostvarenih bodova).

Učenik sa zaključnom ocjenom dovoljan (2) rijetko preispituje svoje razumijevanje za vrijeme nastavnog sata, učenici sa zaključnom ocjenom dobar (3) u jednakoj mjeri rijetko i povremeno procjenjuju svoje razumijevanje za vrijeme nastavnog sata, dok učenici sa zaključnom ocjenom vrlo dobar (4) to u najvećem broju rade povremeno (Slika 3B).

Većina učenica sa zaključnom ocjenom dobar (3) rijetko, ali i prilično često preispituje svoje razumijevanje za vrijeme nastavnog sata, većina učenica sa zaključnom ocjenom vrlo dobar (4) to radi rijetko, dok većina učenica sa zaključnom ocjenom odličan (5) to radi rijetko i povremeno (Slika 3C). 
A

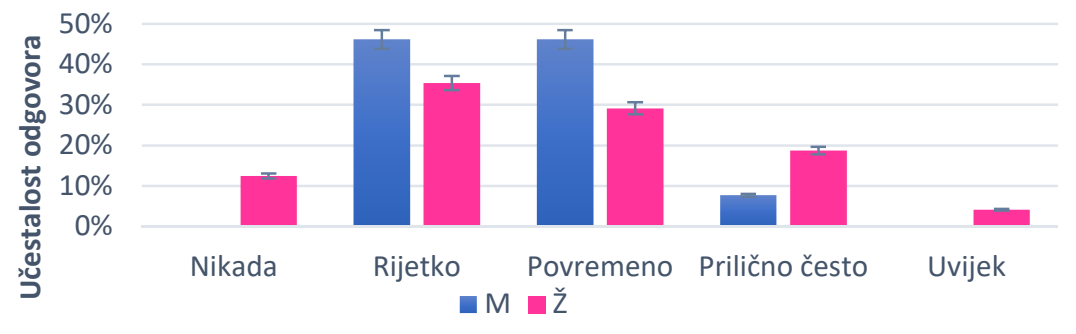

B

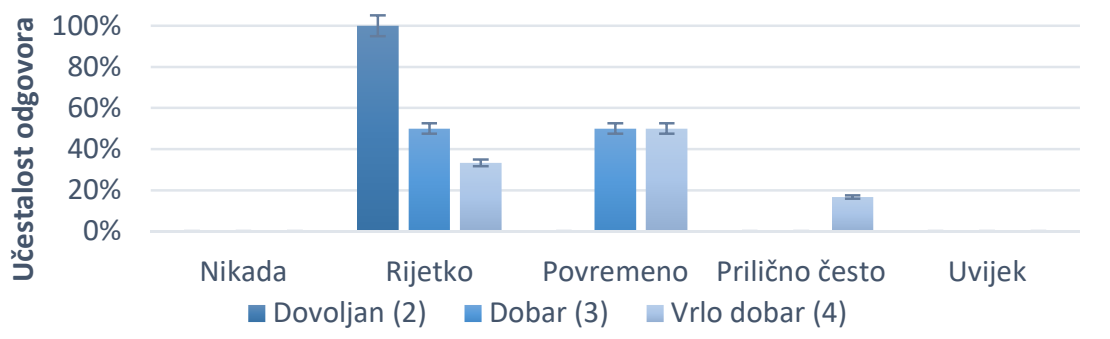

C

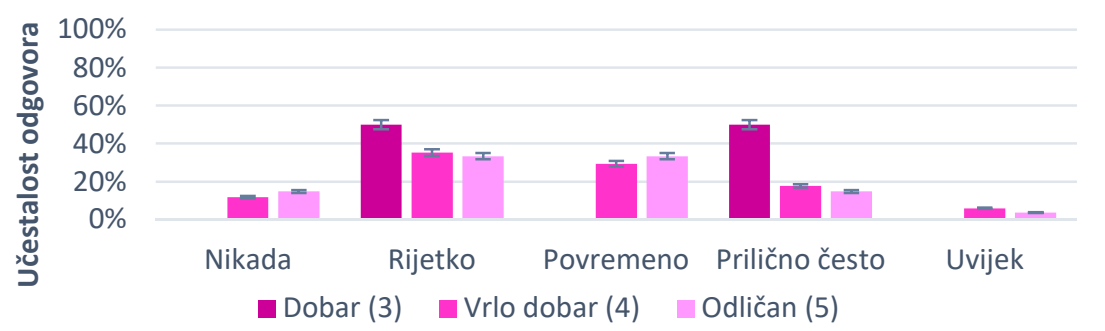

Slika 3 Usporedba odgovora učenika i učenica na tvrdnju „Tijekom nastavnog sata postavljam si različita pitanja kojima preispitujem vlastito razumijevanje sadržaja kojeg učimo." A usporedba odgovora s obzirom na spol; B usporedba odgovora s obzirom na zaključnu ocjenu iz biologije kod učenika; C usporedba odgovora s obzirom na zaključnu ocjenu iz biologije kod učenica

Većina učenika povremeno uspoređuje svoje rezultate s prijašnjim rezultatima u svrhu procjene vlastitog napretka i slabih strana na osnovu kojih planiraju daljnje učenje, dok to većina učenica radi prilično često. Manji broj učenika oba spola to radi rijetko. Također, manji broj učenica je odabrao odgovor nikada, dok se među učenicima ni jedan učenik nije odlučio za taj odgovor (Slika 4A).

Učenik sa zaključnom ocjenom dovoljan (2) rijetko uspoređuje svoje rezultate s prijašnjim rezultatima u svrhu procjene vlastitog napretka i slabih strana na osnovu kojih planira daljnje učenje, dok većina učenika sa zaključnom ocjenom dobar (3) to radi povremeno, a većina učenika sa zaključnom ocjenom vrlo dobar (4) to radi uvijek (Slika 4B).

Većina učenica sa zaključnom ocjenom dobar (3) i većina učenica sa zaključnom ocjenom vrlo dobar (4) tvrdi da prilično često se osvrće na svoje prijašnje rezultate i uspoređuje ih sa sadašnjim rezultatom kako bi uočile svoj napredak i slabe strane na kojima još moraju poraditi te na osnovu toga planiraju daljnje učenje. S druge strane, većina učenica sa zaključnom ocjenom odličan (5) povremeno i uvijek se osvrće na svoje prijašnje rezultate i uspoređuje ih sa sadašnjim rezultatom u svrhu uočavanja svog napretka i slabih strana na kojima još moraju poraditi te na osnovu toga planiraju daljnje učenje (Slika $4 C)$. 


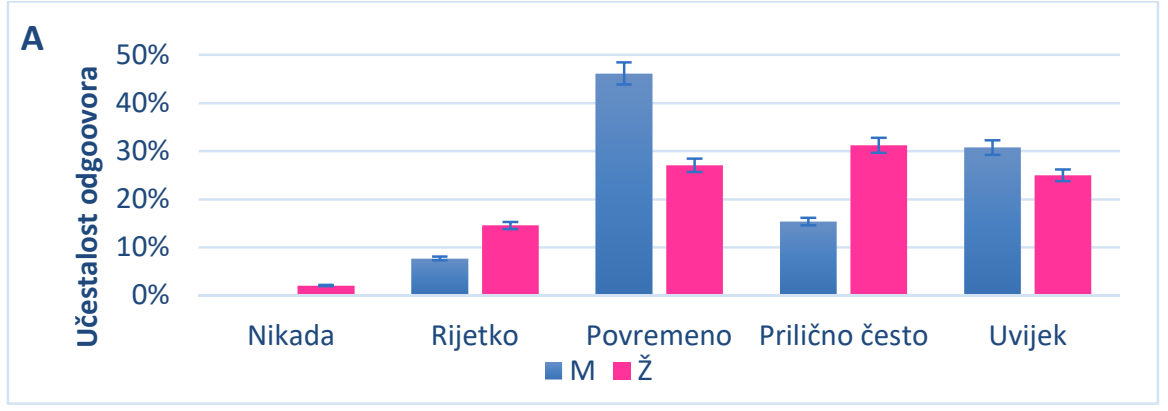

B

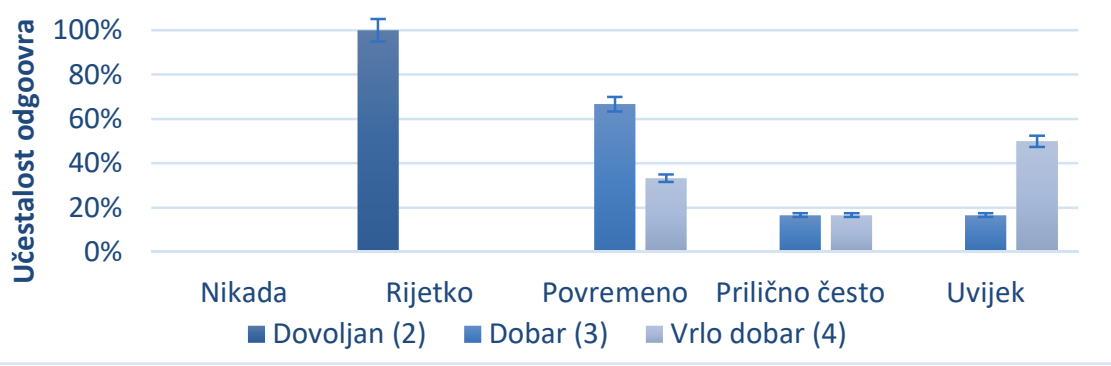

C

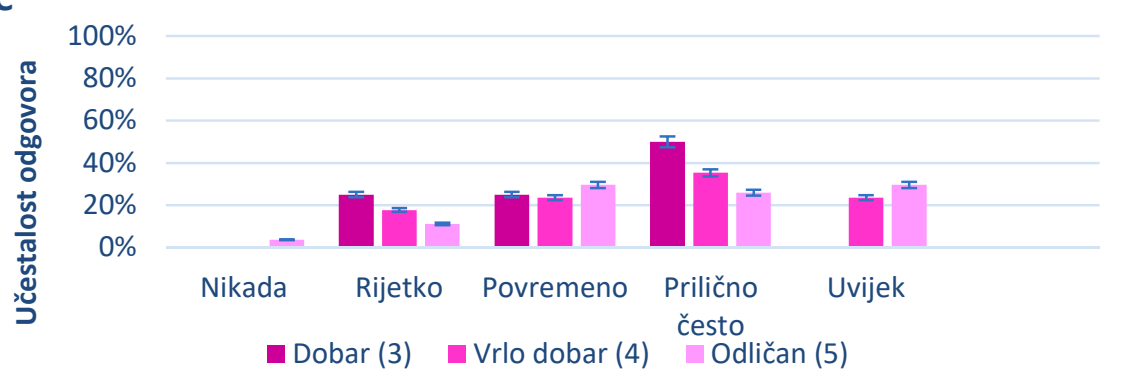

Slika 4 Usporedba odgovora učenika i učenica na tvrdnju „Osvrćem se na svoje prijašnje rezultate i uspoređujem ih sa sadašnjim rezultatom (npr. uspoređujem prijašnji i sadašnji uspjeh na pisanoj provjeri znanja). Pri tome uočavam svoj napredak i slabe strane na kojima još moram poraditi te na osnovu toga planiram daljnje učenje. " A usporedba odgovora s obzirom na spol; B usporedba odgovora s obzirom na zaključnu ocjenu iz biologije kod učenika; C usporedba odgovora s obzirom na zaključnu ocjenu iz biologije kod učenica

U ovom radu istražene su učeničke navike samovrednovanja postignuća s naglaskom na procjenu njihove spremnosti samostalnog prikupljanja povratnih informacija kojima mogu usmjeriti refleksiju, a time i vlastiti proces učenja. Ovako postavljeno istraživanje u skladu je s Hattie i Timperley (2007) koji govore da su povratne informacije specifične informacije koje informiraju učenika o njegovom napretku, slabostima i jakostima te služe u svrhu poboljšanja refleksije.

Objektivna prosudba o sposobnosti samoprocjene postignuća rađena je temeljen analize ostvarenog i očekivanog uspjeha na pisanoj provjeri znanja, dok je subjektivan doživljaj učeničke sposobnosti samoprocjene postignuća analiziran temeljem odgovora učenika na pojedine tvrdnje provedene ankete.

Samoprocjena postignuća odnosno uspjeha ili produkta učenja jedna je od ključnih povratnih informacija kako za učenika tako i za nastavnika. Osiguravanje mjesta u pisanoj provjeri znanja za upis broja očekivanih bodova uz pojedino pitanje način je usmjerenog prikupljanja povratnih informacija odnosno usmjerene refleksije. Također služi i u osamostaljivanju učenika u toj vještini. Nesklad između očekivanih i ostvarenih bodova u pojedinom pitanju jasno ukazuje učenicima i nastavnicima koja znanja 
nedostaju ili koji dio sadržaja je još uvijek nerazumljiv pa otežava izgradnju koncepata i dostizanje znanja na višim kognitivnim razinama.

U provedenom istraživanju uočeno je da učenici precjenjuju svoj uspjeh (slika 1), a rezultati ankete (slika 2) ukazuju da se učenici u velikoj mjeri doživljavaju kao sposobni u točnoj procjeni vlastitog uspjeha. Najobjektivnije su učenice s prosječnom ocjenom dobar koje u najvećem broju smatraju da rijetko mogu procijeniti svoj uspjeh, mada među njima ima i onih koje misle da to mogu prilično često. Analizom odgovora na 17. tvrdnju provedene ankete (prilog 1) vidljivo je da učenici ne precjenjuju svoj uspjeh. Isto tako rijetko ili povremeno se podcjenjuju (tvrdnja 18., prilog 1). Jedino se učenici s ocjenom dobar prilično često podcijene. Nesklad procjene uspjeha na pisanoj provjeri znanja i subjektivnog doživljaja utvrđenog anketom treba gledati s perspektive postojanja iluzije znanja i iluzije mogućnosti točne procjene vlastitog uspjeha. Iluziju znanja potvrđuje rezultat pisane provjere znanja koji ukazuje da su učenici prilično loše riješili pisanu provjeru znanja, a procijenili su ju uspješnije riješenom. Odstupanje između postignutog i očekivanog uspjeha ukazuje na nerazumijevanje gradiva (pisana provjera znanja korištena u ovom istraživanju sastojala se od velikog broja pitanja koja ispituju 2. razinu postignuća prema Crooksovoj taksonomiji). Da su samoprocjene učenika obično veće u odnosu na ocjene nastavnika, potvrđuje i Ross (2006). Prema njemu mogući razlog je što učenici tumače kriterije ocjenjivanja drugačije od nastavnika i pri tome su često orijentirani samo na površne karakteristike svog rada. Također prema Ross (2006) razlog odstupanja između procjene učenika i nastavnika je i taj što učenici u samoprocjenu uključuju informacije koje nastavniku nisu dostupne poput informacija o uloženom trudu. Zato je i opažena veća suglasnost između vršnjačke procjene i samoprocjene, nego između samoprocjene i nastavnikove procjene (Ross, 2006).

Postojanje iluzije znanja potvrđuju i rezultati prikazani na slici 3. Najviše učenika oba spola rijetko i povremeno preispituju vlastito razumijevanje. Čak i među učenicima s boljim uspjehom (vrlo dobar i odličan) ima najviše onih koji to rade rijetko i povremeno, a među učenicima s odlični uspjehom ima više onih koji to nikad ne rade, nego onih koji to uvijek rade. Za ovakvu naviku mogu se pretpostaviti sljedeći razlozi: učenici ili smatraju da razumiju gradivo ili smatraju da je dovoljno reproducirati sadržaj bez razine razumijevanja, a postoji i vjerojatnost da ne znaju određene tehnike učenja kojima bi procijenili vlastito razumijevanje što nam govore i odgovori na prvu tvrdnju u privitku 1.

Tehnike poput KWL tablica, izlaznih karata ili slično dobar su alat za prikupljanje povratnih informacija. Često u praksi prilikom korištenja ovakvih tehnika poput KWL tablice izostane upravo samoprocjena naučenog ili uočavanje konceptualne promjene doživljene tijekom i nakon učenja. Prednost ove tablice je što se može koristiti pri individualnom i grupnom radu kao i u radu u paru pa je osim za samovrednovanje pogodna i za vršnjačko vrednovanje (Krstanac i Horvatin, 2018).

Analiza odgovora tvrdnje prikazane na slici 4 upućuje da među učenicima oba spola (neovisno o uspjehu i u ovisnosti o njemu) postoji određena tendencija osvrta na prijašnje rezultate i usporedbe sa sadašnjim u svrhu uočavanja vlastitog napretka. Koliko uspješno to rade ovisi o tome koliko uspješno mogu samostalno prikupiti konkretne povratne informacije. Ovo je vještina koja se razvija. Učenike je potrebno naučiti kako to raditi, a najbolje uče ako im nastavnik daje povratne informacije pa se polako osamostaljuju. Prema istraživanju koje je provela Kligl (2019) s istim učenicima odgovori ankete govore o tome kako nastavnik ispitivanim učenicima rijetko ili povremeno daje povratnu informaciju. Ovim se da pretpostaviti njihovo nesnalaženje u prikupljanju konkretnih povratnih informacija čime se objašnjava i rezultat samoprocjene uspjeha postignutog na pisanoj provjeri znanja. Kligl (2019) je također u svom istraživanju pokazala da učenici na početku istraživanja imaju veće odstupanje u 
samoprocjeni uspjeha u odnosu na kraj istraživanja u kojem su četiri tjedna bili izloženi vođenim skupljanjem povratnih informacija. lako su i dalje učenici pokazivali neuspjeh u točnoj procjeni svog uspjeha (mogući razlog je prekratak period za svladavanje vještine samovrednovanja), ipak je uočena tendencija objektivnosti. Rezultati prikazani na slici 4 kao i odgovori na 16. tvrdnju (prilog 1) koji upućuju da učenici nastoje pronaći uzroke loše ocjene ukazuju da među ispitivanim učenicima postoji svijest o važnosti samovrednovanja. Ovo potvrđuje i uočena činjenica da najviše ispitivanih učenika smatra da su sami zaslužni za svoj uspjeh (13. tvrdnja, prilog 1), a nastavnik povremeno (tvrdnja 15, prilog 1). Problem neostvarenog potencijala samovrednovanja može se potražiti upravo $u$ nedovoljnom uključivanju učenika u proces vrednovanja. Često učenici sumativno vrednovanje (vrednovanje naučenog) doživljaju kao završen proces na koji više ne mogu utjecati. Ne prepoznaju postignuti uspjeh na pisanoj ili usmenoj provjeri znanja kao povratnu informaciju za usmjeravanje daljnjeg procesa učenja, nego provjere znanja doživljavaju kao ogranke kojima završavaju učenje određenog gradiva. U tom smislu je moguće i da kriterije vrednovanja doživljavaju samo kao standard za postizanje ocjene, a ne kao pomoć u vođenom samovrednovanju. Često kriteriji ocjenjivanja učenicima nisu razumljivi, pa kao takvi i ne mogu poslužiti u samovrednovanju. Zato je potrebno učenicima razjasniti kriterije (Papanthymou i Darra, 2019). Prema ovom istraživanju učenici povremeno ili često percipiraju nastavnika kao onoga koji ih uči kako koristiti kriterije za procjenu uspjeha. Učenici s ocjenom dobar govore da nastavnik ima tu praksu prilično često, a učenice $s$ istom ocjenom navode da to nastavnik uvijek radi (20. tvrdnja, prilog 1). Ovo nas može usmjeriti u zaključak da je nastavnik više orijentiran na lošije učenike nego na one boljeg uspjeha, što je često i praksa u svakodnevnom radu u nastavi. Učenici oba spola se izjašnjavanju u provedenom istraživanju da povremeno i prilično često znaju što se od njih očekuje, na temelju čega će biti ocjenjeni (tvrdnja 19, prilog 1), ali rijetko osmišljavaju kriterije s nastavnikom. Prema Mrkonjić i Vlahović, (2008) nastavnici rijetko prepuštaju učenicima mogućnost vrednovanja njihovog rada jer strahuju od gubitka autoriteta i moći nad svojim učenicima. Većina učenika odgovara da nikad ili rijetko zajedno s nastavnikom osmišljava kriterije ocjenjivanja što je povezano s uspjehom učenika. Ovo upućuje da učenici na temelju iskustva, poznavanja načina ocjenjivanja učenika mogu procijeniti što se od njih očekuje, a ne da vlastito učenje i procjenu vlastitog uspjeha ili napretka uspoređuju s postojećim kriterijima.

Prema Moss i Brookhart, (2009) u tradicionalnim školama nastavnici su nedovoljno upoznati s pojmom samovrednovanja i nemaju dovoljno iskustva i znanja potrebnog za uvođenje takvog oblika vrednovanja. Često se u praksi nastavnici i učitelji izjašnjavaju da nemaju dovoljno vremena davati individualnu povratnu informaciju. Stoga Kyriacou (1995) preporučuje davanje grupnih povratnih informacija, zalaže se za poticanje i usmjeravanje vršnjačkog vrednovanja kao i za samovrednovanje.

Vrednovanjem se uči. Često su učitelji/nastavnici usmjereni samo na vrednovanje postignuća, ali je ključno bazirati se i na vrednovanje procesa učenja. Ovome govori u prilog i rezultat slike 3A u kojoj je vidljivo da većina učenika rijetko i povremeno preispituje svoje razumijevanje za vrijeme nastavnog sata, a odgovori tog pitanja su povezani s ostvarenim uspjehom prikazanim na slici 1 . Kada učenici znaju primiti i/ili kreirati konkretne povratne informacije u smislu da znaju što s njima napraviti onda mogu mijenjati, prilagođavati i usmjeravati vlastiti proces učenja. Konkretne povratne informacije kako o procesu učenja tako i o produktu učenja daju učenicima osjećaj kontrole što je ključno za postizanje motivacije i u konačnici napretka. Osjećaj kontrole pogoduje i doživljavanju ugodnih emocija. Pozitivne emocije povećavaju interes i intrinzičnu motivaciju za učenje, učenici se više trude, samostalno reguliraju učenje bolje se koristeći metakognitivnim strategijama te u konačnici postižu bolji uspjeh (Pekrun i sur, 2002). Vrednovanjem se stvara poticajno okruženje. Poticajno okruženje je 
ono koje osigurava dobru emocionalnu i kognitivnu podršku učenicima te u kojem učenici prepoznaju korisnost sadržaja kojeg uče za svakodnevni život (Eccles i Roeser, 2009).

Dosadašnja istraživanja su utvrdila da je motivacija i korištenje strategija samoreguliranog učenja predmetno uvjetovana (Wolters i Pintrich, 1998). Stoga je provedeno istraživanje potrebno proširiti te ispitati navike učenja i samovrednovanja postignuća i u ostalim nastavnim predmetima na većem uzorku ispitanika. Također je potrebno utvrditi navike i spremnost učenika (i učitelja/nastavnika) u samovrednovanju procesa učenja.

\section{ZAKLUČAK}

Istraživanjem je utvrđen nesklad između ostvarenog i očekivanog uspjeha, kao i nesklad između percipirane i stvarne sposobnosti točne samoprocjene vlastitog uspjeha. Učenici precjenjuju svoj uspjeh i vlastite mogućosti samoprocjene znanja. Kod učenika je utvrđeno da postoji svijest o važnosti samovredovanja, ali im nedostaje iskustvo. Potrebna im je pomoć i podrška u primanju, uočavanju i kreiranju konkretnih povratnih informacija kako bi mogli uspješno napraviti samorefleksiju i usmjeriti vlastiti proces učenja.

\section{METODIČKI ZNAČAJ}

Predloženo predviđeno bodovanje očekivanog broja bodova u pisanoj provjeri znanja može poslužiti učeniku, učitelju i nastavniku kao smjernica za brzu i laku procjenu uspješnosti rješavanja te kao konkretna povratna informacija za pristupe vrednovanja za učenje i kao učenje. Također anketa može poslužiti u svakodnevnoj nastavnoj praksi učitelju/nastavniku da utvrdi stupanj samostalnosti učenika u samovrednovanju te tako usmjeri vlastito poučavanje primjenom vrednovanja za učenje. Ista anketa može poslužiti i učenicima u samoprocjeni vlastite sposobnosti i navika samovrednovanja kao bi mogli usmjeriti svoje učenje korištenjem pristupa vrednovanja kao učenje.

\section{ZAHVALA}

Zahvaljujemo se svim učenicima i nastavnici jedne gimnazije u Osijeku na sudjelovanju u ovom istraživanju. Ovaj rad je nastao tijekom istraživanja za potrebe izrade diplomskog rada pod nazivom „Utjecaj samovrednovanja učeničkog procesa učenja na rezultate učenja“ obranjenog 27. rujna 2019. godine .

\section{LITERATURA}

Andrade, H., Valtcheva, A. (2009). Promoting Learning and Achievement Through SelfAssessment. Theory Into Practice, 48, 12-19.

Bogut, I., Đumlija, S., Lukačević, K., Marceljak Ilić, M. (2012). Biologija 1. Udžbenik iz biologije za prvi razred gimnazije. Zagreb, Alfa

Brookhart, S.M. (2008). How to give effective feedback to your students. Virginia USA, ASCD

Brown, G. T. L., Harris, L. R. (2013). Student self-assessment. In J. H. McMillan (Ed.), SAGE

Bursać, L., Dadić, J., Kisovar-Ivanda, T. (2016). Učeničkim samovrednovanjem do kvalitetnih učeničkih postignuća. Magistra ladertina, 11, 74-87.

Burušić, J. (1999). Kakve kategorije rabimo u upitnicima i skalama procjena? Društvena istraživanja, 8, 137-152.

Cavilla, D. (2017). The Effects of Student Reflection on Academic Performance and Motivation. SAGE Open, 7, 1-13.

Cindrić, M., Miljković, D., Strugar, V. (2010). Didaktika i kurikulum. Zagreb, IEP-D2

Cowie, B. (2005). Pupil commentary on assessment for learning. The Curriculum Journal, 16, 137-151.

Crooks, T. J. (1988). The impact of classroom evaluation practices on students. Review of Educational Research, 58, 438481.

de Bilde, J., Vansteenkiste, M., Lens, W. (2011). Understanding the association between future time perspective and selfregulated learning through the lens of self-determination theory. Learning and Instruction, 21, 332-344.

Duckworth, A., Seligman, M. (2005). Self-discipline outdoes IQ in predicting academic performance of adolescents. Psychol. Sci, 16, 939-944.

Duckworth, A., Seligman, M. (2006). Self-discipline gives girls the edge: gender in self-discipline, grades, and achievement test scores. J. Edu. Psychol, 98, 198-208. 
Earl, L., Katz, S. (2006). Rethinking classroom assessment with purpose in mind: assessment for learning, assessment as learning, assessment of learning. Manitoba, Canada, Manitoba Education, Citizenship and Youth

Eccles, J.S., Roeser, R.W. (2009). Schools, Academic Motivation, and Stage-Environment Fit. In Lerner, R.M., Steinber, L. (Eds.) Handbook of adolescent psychology (3rd ed.. Hoboken, N.J.: John Wiley \& Sons. 404-434

Hattie, J., Timperley, H. (2007). The power of feedback. Review of Educational Research, 77, 81-112.

Hunjek, M. (2015). Vrednovanje kao strategija učenja matematike. Diplomski rad. Sveučilište u Zagrebu, Prirodoslovno matematički fakultet, Zagreb.

Kadhiravan, S. (2012). Self-regulated learning of adolescents in relation to their achievement motivation. Journal of Psychosocial Research, 7, 211-218.

Kligl, I. (2019). Utjecaj samovrednovanja učeničkog procesa učenja na rezultate učenja. Diplomski rad. Sveučilište Josipa Jurja Strossmayera u Osijeku, Odjel za biologiju, Osijek.

Krstanac, Ž., Horvatin, K. (2018). Priručnik za nastavnike biologije: 1. razred srednje škole. Zagreb, CARNET

Kuhl, P., Hannover, B. (2012). Differenzielle Benotungen von Mädchen und Jungen: Der Einfluss der von der Lehrkraft eingeschätzten Kompetenz zum selbstgesteuerten Lernen [Different grading for girls versus boys? Examining the impact of students' ability for self-regulated learning as perceived by their teachers]. Z. Entwicklungspsychol. Pädagog. Psychol. 44, 153-162.

Kyriacou, C. (1995). Temeljna nastavna umijeća: metodički priručnik za uspješno poučavanje i učenje. Zagreb, Educa Matijević, M. (2004). Ocjenjivanje u osnovnoj školi. Zagreb, Tipex

McMillan, J. H., Hearn, J. (2008). Student self-assessment: The key to stronger student motivation and higher achievement. Educational Horizons, 87, 40-49.

Moss, C., Brookhart, S. (2009). Advancingformativeassessment on everyclassroom: a guide for instructionalleaders. Alexandria. USA. ASCD publications

Mrkonjić, A., Vlahović, J. (2008). Vrednovanje u školi. Acta ladertina, 5, 27-37.

Papanthymou, A., Darra, M. (2019). Student Self-Assessment in Primary and Secondary Education in Greece and Internationally. World Journal of Educational Research, 6, 50-75.

Pekrun, R., Goetz, T., Titz, W., Perry, R.P. (2002). Academic emotions in students' self-regulated learning and achievement: A program of qualitative and quantitative research. Educational Psychologist, 37, 91-105.

Penca Palčić, M. (2008). Utjecaj provjeravanja i ocjenjivanja znanja na učenje. Život i škola, 19, 137-148.

Ross, J.A. (2006). The Reliability, Validity, and Utility of Self-Assessment. Practical Assessment Research \& Evaluation, 11, 1 13.

Suchodoletz, A. V., Trommsdorff, G., Heikamp, T., Wieber, F., Gollwitzer, P. M. (2009). Transition to school: the role of kindergarten children's behavior regulation. Learn. Individ. Differ. 19, 561-566.

Wolters, C.A., Pintrich, P.R. (1998). Contextual differences in student motivation and self-regulated learning in mathematics, English and social studies classrooms. Instructional science, 26, 27-47.

Wong, H. M. (2017). Implementing self-assessment in Singapore primary schools: effects on students' perceptions of selfassessment. Pedagogies: An International Journal, 12, 391- 409.

Zimmerman, B. J., Moylan, A. R. (2009). Self-regulation: Where metacognition and motivation intersect. In Hacker, D. J., Dunlosky, J., Graesser, A. C. (Eds.), Handbook of metacognition in education (pp. 299-315). New York, NY: Routledge.

\section{PRILOZI}

Prilog 1 Usporedba odgovora učenika prema spolu i zaključnim ocjenama iz biologije na kraju 2. razreda gimnazije (izraženo u postotcima \%)

\begin{tabular}{|c|c|c|c|c|c|c|c|c|c|}
\hline \multirow{3}{*}{ TVRDNJA } & \multirow{3}{*}{$\begin{array}{c}\text { SKALA } \\
\text { PROCJENE }\end{array}$} & M & ž & 4 & 3 & 2 & 5 & 4 & 3 \\
\hline & & \multirow{2}{*}{\multicolumn{2}{|c|}{ SPOL }} & & $M$ & & & Ž & \\
\hline & & & & \multicolumn{6}{|c|}{ SPOL/USPJEH } \\
\hline \multirow{5}{*}{$\begin{array}{l}\text { 1. Na satu procjenjujem svoje } \\
\text { razumijevanje, znanje i napredak } \\
\text { ispunjavanjem različitih obrazaca } \\
\text { (npr. KWL tablica, izlazne karte, } \\
321 \text { procjeni, post-it papirići, } \\
\text { minuta za kraj). }\end{array}$} & Nikada & 53,85 & 43,75 & 50,00 & 50,00 & 100,00 & 44,44 & 41,18 & 50,00 \\
\hline & Rijetko & 30,77 & 37,50 & 16,67 & 50,00 & 0,00 & 33,33 & 41,18 & 50,00 \\
\hline & Povremeno & 7,69 & 12,50 & 16,67 & 0,00 & 0,00 & 11,11 & 17,65 & 0,00 \\
\hline & Prilično često & 7,69 & 6,25 & 16,67 & 0,00 & 0,00 & 11,11 & 0,00 & 0,00 \\
\hline & Uvijek & 0,00 & 0,00 & 0,00 & 0,00 & 0,00 & 0,00 & 0,00 & 0,00 \\
\hline \multirow{5}{*}{$\begin{array}{l}\text { 2. Tijekom učenja procjenjujem } \\
\text { što sam naučio/la, je li to dovoljno } \\
\text { i trebam li još učiti. }\end{array}$} & Nikada & 0,00 & 2,08 & 0,00 & 0,00 & 0,00 & 0,00 & 5,88 & 0,00 \\
\hline & Rijetko & 7,69 & 6,25 & 16,67 & 0,00 & 0,00 & 3,70 & 11,76 & 0,00 \\
\hline & Povremeno & 23,08 & 16,67 & 0,00 & 50,00 & 0,00 & 11,11 & 23,53 & 25,00 \\
\hline & Prilično često & 46,15 & 29,17 & 33,33 & 50,00 & 100,00 & 37,04 & 17,65 & 25,00 \\
\hline & Uvijek & 23,08 & 45,83 & 50,00 & 0,00 & 0,00 & 48,15 & 41,18 & 50,00 \\
\hline \multirow{5}{*}{$\begin{array}{l}\text { 3. Odabirem tehniku učenja koja } \\
\text { odgovara zahtjevima pojedinog } \\
\text { gradiva. }\end{array}$} & Nikada & 0,00 & 0,00 & 0,00 & 0,00 & 0,00 & 0,00 & 0,00 & 0,00 \\
\hline & Rijetko & 23,08 & 6,25 & 16,67 & 33,33 & 0,00 & 3,70 & 11,76 & 0,00 \\
\hline & Povremeno & 15,38 & 16,67 & 33,33 & 0,00 & 0,00 & 18,52 & 17,65 & 0,00 \\
\hline & Prilično često & 30,77 & 27,08 & 0,00 & 50,00 & 100,00 & 25,93 & 23,53 & 50,00 \\
\hline & Uvijek & 30,77 & 50,00 & 50,00 & 16,67 & 0,00 & 51,85 & 47,06 & 50,00 \\
\hline
\end{tabular}




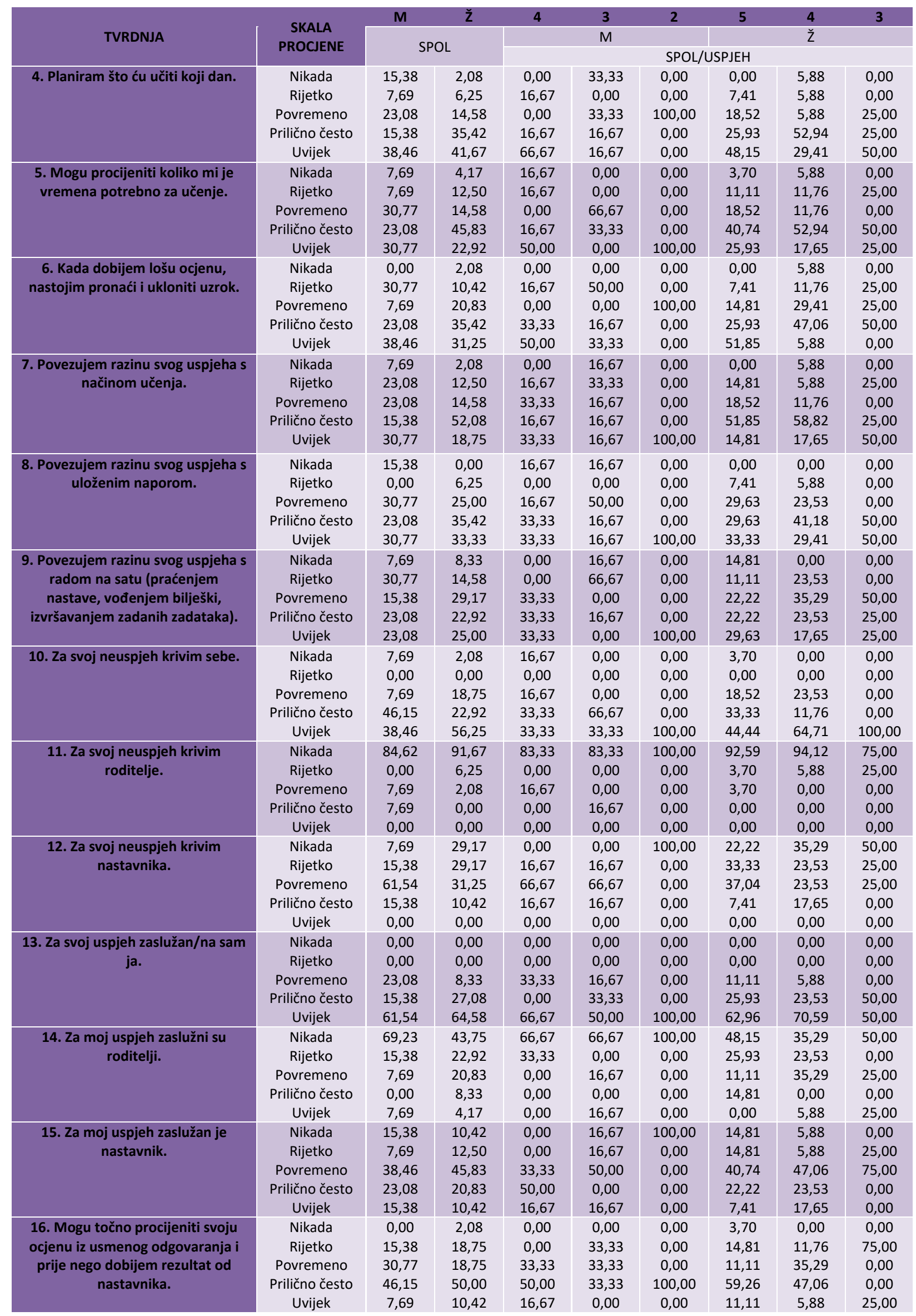




\begin{tabular}{|c|c|c|c|c|c|c|c|c|c|}
\hline \multirow{3}{*}{ TVRDNJA } & \multirow{3}{*}{$\begin{array}{l}\text { SKALA } \\
\text { PROCJENE }\end{array}$} & M & ž & 4 & 3 & 2 & 5 & 4 & 3 \\
\hline & & \multirow{2}{*}{\multicolumn{2}{|c|}{ SPOL }} & \multirow{2}{*}{\multicolumn{6}{|c|}{ SPOL/USPJEH }} \\
\hline & & & & & & & & & \\
\hline \multirow{5}{*}{$\begin{array}{l}\text { 17. Ocjena koju dobijem za svoj } \\
\text { rad manja je od one koju } \\
\text { očekujem. }\end{array}$} & Nikada & 15,38 & 4,17 & 16,67 & 0,00 & 100,00 & 0,00 & 11,76 & 0,00 \\
\hline & Rijetko & 46,15 & 47,92 & 66,67 & 33,33 & 0,00 & 59,26 & 35,29 & 25,00 \\
\hline & Povremeno & 30,77 & 37,50 & 16,67 & 50,00 & 0,00 & 37,04 & 29,41 & 75,00 \\
\hline & Prilično često & 7,69 & 8,33 & 0,00 & 16,67 & 0,00 & 3,70 & 17,65 & 0,00 \\
\hline & Uvijek & 0,00 & 2,08 & 0,00 & 0,00 & 0,00 & 0,00 & 5,88 & 0,00 \\
\hline \multirow{5}{*}{$\begin{array}{l}\text { 18. Ocjena koju dobijem za svoj } \\
\text { rad veća je od one koju očekujem. }\end{array}$} & Nikada & 7,69 & 4,17 & 16,67 & 0,00 & 0,00 & 3,70 & 5,88 & 0,00 \\
\hline & Rijetko & 38,46 & 35,42 & 33,33 & 50,00 & 0,00 & 33,33 & 41,18 & 25,00 \\
\hline & Povremeno & 38,46 & 52,08 & 33,33 & 33,33 & 100,00 & 51,85 & 47,06 & 75,00 \\
\hline & Prilično često & 15,38 & 8,33 & 16,67 & 16,67 & 0,00 & 11,11 & 5,88 & 0,00 \\
\hline & Uvijek & 0,00 & 0,00 & 0,00 & 0,00 & 0,00 & 0,00 & 0,00 & 0,00 \\
\hline \multirow{5}{*}{$\begin{array}{l}\text { 19. Unaprijed znam što se od } \\
\text { mene očekuje, na temelju čega ću } \\
\text { biti ocijenjen i na koji način. }\end{array}$} & Nikada & 0,00 & 0,00 & 0,00 & 0,00 & 0,00 & 0,00 & 0,00 & 0,00 \\
\hline & Rijetko & 30,77 & 18,75 & 33,33 & 33,33 & 0,00 & 18,52 & 17,65 & 25,00 \\
\hline & Povremeno & 53,85 & 27,08 & 50,00 & 50,00 & 100,00 & 18,52 & 41,18 & 25,00 \\
\hline & Prilično često & 7,69 & 31,25 & 0,00 & 16,67 & 0,00 & 37,04 & 29,41 & 0,00 \\
\hline & Uvijek & 7,69 & 22,92 & 16,67 & 0,00 & 0,00 & 25,93 & 11,76 & 50,00 \\
\hline \multirow{5}{*}{$\begin{array}{l}\text { 20. Zajedno s nastavnikom } \\
\text { osmišljavamo kriterije prema } \\
\text { kojima će naš rad biti ocijenjen. }\end{array}$} & Nikada & 23,08 & 27,08 & 33,33 & 16,67 & 0,00 & 18,52 & 41,18 & 25,00 \\
\hline & Rijetko & 46,15 & 29,17 & 33,33 & 50,00 & 100,00 & 37,04 & 23,53 & 0,00 \\
\hline & Povremeno & 23,08 & 18,75 & 33,33 & 16,67 & 0,00 & 18,52 & 23,53 & 0,00 \\
\hline & Prilično često & 7,69 & 22,92 & 0,00 & 16,67 & 0,00 & 25,93 & 11,76 & 50,00 \\
\hline & Uvijek & 0,00 & 2,08 & 0,00 & 0,00 & 0,00 & 0,00 & 0,00 & 25,00 \\
\hline \multirow{5}{*}{$\begin{array}{l}\text { 21. Nastavnik nas uči kako na } \\
\text { ispravan način koristiti kriterije za } \\
\text { procjenu našeg rada. }\end{array}$} & Nikada & 7,69 & 8,33 & 16,67 & 0,00 & 0,00 & 7,41 & 11,76 & 0,00 \\
\hline & Rijetko & 30,77 & 29,17 & 33,33 & 16,67 & 100,00 & 29,63 & 29,41 & 25,00 \\
\hline & Povremeno & 23,08 & 35,42 & 16,67 & 33,33 & 0,00 & 29,63 & 47,06 & 25,00 \\
\hline & Prilično često & 38,46 & 16,67 & 33,33 & 50,00 & 0,00 & 22,22 & 11,76 & 0,00 \\
\hline & Uvijek & 0,00 & 10,42 & 0,00 & 0,00 & 0,00 & 11,11 & 0,00 & 50,00 \\
\hline
\end{tabular}

